\title{
ARAH DAN KECEPATAN ARUS PERAIRAN SEKITAR PULAU BUNAKEN PADA PERIODE UMUR BULAN PERBANI DI MUSIM PANCAROBA II
}

\author{
(Surface Current Direction And Velocity of Bunaken Waters During Spring Tide in \\ Second Transition Season) \\ Robert J. Modalo ${ }^{1 *}$, Royke M. Rampengan ${ }^{1}$, Esry T. Opa ${ }^{1}$ \\ Rignolda Djamaluddin ${ }^{1}$, Hermanto W. K. Manengkey ${ }^{1}$, Nego E. Bataragoa ${ }^{2}$
}

1. Program Studi Ilmu Kelautan, Fakultas Perikanan dan Ilmu Kelautan, Universitas Sam Ratulangi, Manado.

2. Program Studi Manajemen Sumberdaya Perairan, Fakultas Perikanan dan Ilmu Kelautan, Universitas Sam Ratulangi, Manado.

*e-mail : robertjmodalo@gmail.com

Current is a movement of water masses to the equilibrium that causes the the water masses to move horizontal and vertical. The purpose of this research was to describe the direction and velocity of surface currents in the waters around Bunaken Island, and to analyze the surface current velocity and direction data measured from the waters around Bunaken Island both spatially and temporally (at high and low tide). The resulting velocities of the current during high tide were in the range of 0.05 to 2.50 knots, whereas during the low tide were in the range of 0.02 to 1.53 knots. When the water moved to the high tide, the data showed that almost $50 \%$ of the resulting current velocities were below $0.50 \mathrm{knot}$, when the water moved to the low tide, about $50 \%$ frequency of occurring velocities were between 0.50 to 1.00 knot. When the water moved in, the frequency of resulting current direction showed that most of the water masses led to the East, which represent $27.27 \%$ of the whole data. As the water moved out, the resulting direction of the water mass flew mostly to the Southeast, which as much as $22.73 \%$. The fluctuations in velocity and direction of the water mass movements around Bunaken Island measured on a short temporal scale (30 seconds) showed relatively in constant conditions. Only in certain places showed major change in both the velocity and the direction of the current.

Keywords : Bunaken Island, Sea surface current

Arus merupakan proses pergerakan massa air menuju kesetimbangan yang menyebabkan perpindahan massa air secara horizontal dan vertikal. Penelitian ini diarahkan untuk mendeskripsikan arah dan kecepatan arus permukaan di perairan sekitar Pulau Bunaken serta menganalisis data kecepatan dan arah arus permukaan secara spasial dan temporal (saat pasang dan saat surut) di perairan sekitar Pulau Bunaken. Resultan kecepatan arus saat air bergerak pasang terukur berada pada kisaran 0,05 sampai 2,50 knot, sedangkan saat air bergerak surut berada pada kisaran 0,02 sampai 1,53 knot. Saat air bergerak pasang hampir $50 \%$ frekuensi kejadian resultan arusnya berkecepatan $<0,50 \mathrm{knot}$, saat air bergerak surut sekitar $50 \%$ frekuensi kejadiannya berada pada resultan kecepatan antara 0,50 sampai 1,00 knot. Frekuensi kejadian resultan arah arus saat air bergerak pasang terbanyak mengarah ke Timur, yaitu sebesar $27,27 \%$. Saat air bergerak surut, resultan arah pergerakan arus terbanyak mengarah ke Tenggara, yaitu sebanyak $22,73 \%$. Secara spasial, fluktuasi kecepatan dan arah arus perairan sekitar Pulau Bunaken yang terukur pada skala temporal yang singkat (30 detik) memperlihatkan kondisi relatif konstan. Hanya pada beberapa tempat tertentu memperlihatkan kejadian perubahan baik kecepatan dan arah arusnya.

Kata kunci : Pulau Bunaken, Arus permukaan laut 


\section{PENDAHULUAN}

Wilayah perairan laut di Sulawesi Utara yang dikenal sebagai salah satu tujuan wisata adalah perairan Taman Nasional Bunaken. Kawasan ini telah ditetapkan sebagai Taman Nasional yang diandalkan oleh Pemerintah Sulawesi Utara dan Kota Manado khususnya sebagai kawasan wisata yang dapat menjadi sumber pendapatan bagi daerah (Rares, 2015). Kawasan perairan ini terkenal dengan kehidupan laut yang beranekaragam dan menarik sebagai objek pariwisata. Beberapa contoh diantaranya adalah ekosistem terumbu karang yang menjadi tempat hidup berbagai organisme laut (Towoliu, 2014) dan ekosistem lamun yang secara ekologis menyediakan nutrien bagi kelangsungan hidup organisme perairan itu sendiri (Wagey, 2017). Keindahan alam bawah laut tersebut telah lama dimanfaatkan oleh masyarakat baik lokal maupun global.

Oseanografi fisika dapat menjadi salah satu alat untuk mempelajari fenomena-fenomena alam laut. Variabel-variabel yang dikaji dalam oseanografi fisika antara lain gelombang, pasang surut dan tenagatenaga pembangkitnya, dan arus laut (Hutabarat dan Evans, 1985). Parameter-parameter yang dapat dikumpulkan dari pengumpulan data arus mencakup faktor pembangkit arus, kecepatan arus, arah arus, dan pola arus (Stowe, 1987).

$$
\text { Data-data }
$$

oseanografi

khususnya arus permukaan diharapkan dapat menjadi acuan kegiatan-kegiatan pemanfaatan ruang laut seperti transportasi masyarakat maupun barang, dan khusus di Taman Nasional Bunaken akan sangat membantu pemanfaatan dan pengelolaan pariwisatanya. Selain itu, masyarakat di dalam atau sekitar Pulau Bunaken yang umumnya nelayan, memanfaatkan perairan tersebut sebagai sumber mata pencarian mereka (Setiawan et al., 2013; Rompas et al., 2015).

Berbagai kegiatan yang dilakukan dapat menghasilkan berbagai limbah yang dapat mencemari perairan, di antaranya limbah minyak buangan kapal-kapal maupun perahu-perahu nelayan setempat. Limbah-limbah rumah tangga yang pada umumnya dibuang ke laut tentu saja dapat juga mencemari perairan dan merusak kehidupan laut. Limbah-limbah tersebut akan menyebar ke perairan lain oleh arus kemudian dapat menimbulkan dampak negatif di perairan tersebut.

Dewasa ini, belum didapatkan informasi yang memadai tentang kondisi oseanografi fisik terlebih khusus informasi kecepatan dan arah arus permukaan di perairan sekitar Pulau Bunaken. Berdasarkan pertimbangan tersebut, maka penelitian mengenai arus permukaan di perairan sekitar Pulau Bunaken sangat penting untuk dilakukan untuk menyediakan informasi yang lebih memadai sebagai acuan untuk pemanfaatan dan pengelolaan.

Penelitian ini dilakukan dengan tujuan untuk mendeskripsikan arah dan kecepatan arus permukaan di perairan sekitar Pulau Bunaken serta menganalisis data kecepatan dan arah arus permukaan secara spasial dan temporal (saat pasang dan saat surut) di perairan sekitar Pulau Bunaken.

\section{METODE PENELITIAN}

\section{Lokasi Penelitian}

Pengambilan data arus dilaksanakan di perairan sekitar Pulau Bunaken pada 53 lokasi pengukuran (gambar 1). Setiap lokasi pengukuran diukur saat air pasang dan surut pada periode umur bulan perbani musim pancaroba II (13 sampai 15 Oktober 2017). Data yang diperoleh selanjutnya 


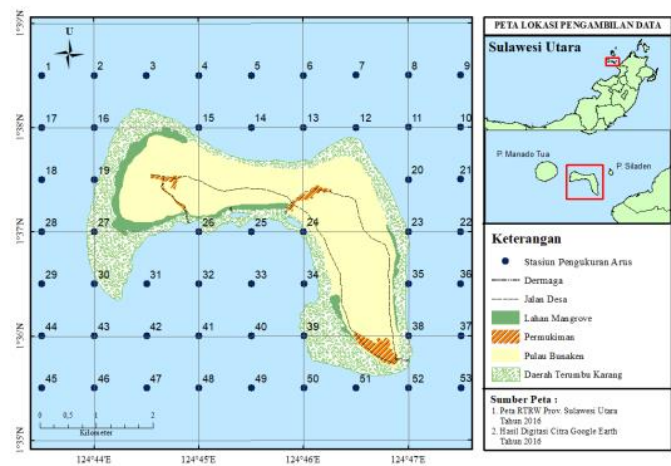

Gambar 1. Peta lokasi pengukuran arus

Tabel 1. Alat dan bahan

\begin{tabular}{|c|c|c|}
\hline No. & Nama & Kegunaan \\
\hline 1. & Peta & $\begin{array}{l}\text { Peta dasar dan } \\
\text { acuan }\end{array}$ \\
\hline 2. & $\begin{array}{l}\text { Floater } \\
\text { Current } \\
\text { Meter }\end{array}$ & Pengukur arus \\
\hline 3. & $\begin{array}{l}\text { Palem } \\
\text { Pasut }\end{array}$ & Pengukur pasut \\
\hline 4. & Stopwatch & Pengukur waktu \\
\hline 5. & $\begin{array}{l}\text { Global } \\
\text { Positioning } \\
\text { System } \\
\text { (GPS) }\end{array}$ & $\begin{array}{l}\text { Penentu posisi } \\
\text { geografis }\end{array}$ \\
\hline 6. & $\begin{array}{l}\text { Perahu } \\
\text { Motor } \\
\text { Tempel }\end{array}$ & Transportasi \\
\hline 7. & Komputer & $\begin{array}{l}\text { Pengolah kata, } \\
\text { data, tabel, } \\
\text { grafik, dan peta }\end{array}$ \\
\hline 8. & Printer & $\begin{array}{l}\text { Pencetak } \\
\text { dokumen }\end{array}$ \\
\hline 9. & $\begin{array}{l}\text { Alat tulis } \\
\text { menulis }\end{array}$ & Mencatat data \\
\hline 10. & Kamera & Dokumentasi \\
\hline
\end{tabular}

diolah dan dianalisis di Laboratorium Geoorfologi Pantai, FPIK UNSRAT.

\section{Prosedur Pengukuran Arus}

Prosedur pengukuran arus mengikuti aturan sesuai metode lagrangian dengan jumlah 53 lokasi pengukuran. Pada setiap lokasi dilakukan empat kali pencatatan posisi (titik koordinat) FCM dalam selang waktu masing-masing 30 detik. Posisi awal FCM dicatat setelah dilepaskan ke perairan kemudian dibiarkan hanyut. Setelah 30 detik dicatat kembali posisi FCM sementara FCM tetap bergerak. Setelah 30 detik berselang dicatat kembali posisi FCM yang ketiga dan 30 detik kemudian dicatat posisi FCM yang terakhir. Prosedur ini selanjutnya dilakukan kembali pada lokasi pengukuran kedua, ketiga, dan seterusnya.

\section{Pengukuran Pasut}

Pasang surut diamati secara langsung dengan menggunakan palem pasut. Pengamatan dilakukan dengan cara membaca skala pada palem pasut yang terkena permukaan air setiap lima belas menit selama pengukuran arus dilakukan kemudian dihentikan setelah pengukuran arus selesai. Data hasil pengukuran pasut digunakan sebagai acuan untuk mengelompokkan data arus.

\section{Analisis Data}

Data hasil pengukuran arus diolah dan dianalisis kemudian disajikan secara deskriptif dalam bentuk tabel dan peta. Pengolahan data dikerjakan menggunakan komputer dengan perangkat lunak (Microsoft Word, Excel, dan Surfer) dengan tahapan sebagai berikut (Ariston, 2010 dalam Siwy, 2012)

1) Data hasil pengukuran arus berupa titik-titik koordinat (empat titik koordinat yang berurutan pada setiap lokasi), kemudian dicatat dan diurutkan sesuai dengan nomor lokasi.

2) Titik-titik koordinat hasil pengukuran diolah untuk menentukan arah dan kecepatan arus kemudian disajikan dalam tabel. Nilai kecepatan arus (V) adalah kecepatan dari koordinat pertama sampai terakhir setiap titik 
lokasi pengukuran. Nilai $\mathrm{V}$ dapat dihitung dengan persamaan :

$\mathrm{V}=$ Resultan $\mathrm{s} / \mathrm{t} \ldots \ldots \ldots$. . (1.)

di mana :

$\mathrm{V}=$ kecepatan arus (m/det)

Resultan $\mathrm{s}=$ Resultan jarak perpindahan FCM $(\mathrm{m})$

$\mathrm{T}=$ waktu (dtk)

Nilai kecepatan arus yang didapatkan kemudian dikonversi ke dalam satuan knot. Nilai t yaitu 90 detik untuk setiap perpindahan FCM dari koordinat pertama ke koordinat terakhir pada setiap lokasi pengukuran. Nilai resultan $\mathrm{S}$ adalah jumlah dari nilai $S$ seluruh perpindahan koordinat. Nilai S dapat dihitung dengan mengolah data koordinat bujur $(\mathrm{X})$ dan lintang $(\mathrm{Y})$ dengan persamaan berikut (Rampengan, 2009) :

Perpindahan koordinat ada tiga kali, maka :

$$
\begin{aligned}
\left(S_{1}\right)^{2} & =\left(X_{1}-X_{0}\right)^{2}+\left(Y_{1}-Y_{0}\right)^{2} \ldots \ldots(2 .) \\
\left(S_{2}\right)^{2} & =\left(X_{2}-X_{1}\right)^{2}+\left(Y_{2}-Y_{1}\right)^{2} \ldots \ldots(3 .) \\
\left(S_{3}\right)^{2} & =\left(X_{3}-X_{2}\right)^{2}+\left(Y_{3}-Y_{2}\right)^{2} \ldots \ldots(4 .) \\
\text { di mana } & : \\
S_{1} & =j a r a k X_{0}, Y_{0} \text { ke } X_{1}, Y_{1}(m) \\
S_{2} & =j a r a k X_{1}, Y_{1} \text { ke } X_{2}, Y_{2}(m) \\
S_{3} & =\text { jarak } X_{2}, Y_{3} \text { ke } X_{3}, Y_{3}(m)
\end{aligned}
$$

Satuan nilai S adalah meter. Karena itu nilai jarak bujur dan lintang antar koordinat dikonversi ke dalam satuan meter yaitu dengan mengalikan nilai jarak tersebut dengan 110.000 meter yang merupakan nilai jarak dalam meter pada setiap jarak satu derajat koordinat di sekitar equator.

Arah arus $\left(\theta^{0}\right)$ didasarkan pada arah pergerakan FCM dari koordinat pertama $\left(X_{0} Y_{0}\right)$ langsung ke koordinat terakhir $\left(X_{3}, Y_{3}\right)$, di mana besar arah berpatokan pada $0^{0}$ Utara bumi. Arah arus diperoleh dengan mencari nilai sudut alpha ( $\alpha$ ) yang dibentuk oleh sisi samping dan sisi miring $X_{0}, Y_{0}$ ke $X_{3}, Y_{3}$ kemudian dijumlahkan atau dikurangkan dengan sudut istimewa berdasarkan letak kuadran $\left(\mathrm{X}_{3}, \mathrm{Y}_{3}\right)$ (persamaan 5). $\Theta^{0}=$ sudut istimewa (+/-) $\alpha^{0} \ldots$. (5) $\alpha^{0}=\left|\operatorname{atg}\left(Y_{3} / X_{3}\right)\right| \ldots \ldots \ldots \ldots(6)$ keterangan :

$$
\begin{array}{lll}
\theta^{0} & = & \text { arah arus } \\
\alpha^{0} & = & \text { sudut alpha } \\
\text { atg } & = & \text { arctangen }
\end{array}
$$

Di bawah ini adalah syarat nilai sudut istimewa yang digunakan berdasarkan muatan nilai $X_{3}$ dan $Y_{3}$ pada koordinat :

1. Jika $X=+$ dan $Y=+$, maka arah adalah $90^{\circ}-\alpha$

2. Jika $X=+$ dan $Y=-$, maka arah adalah $90^{\circ}+\alpha$

3. Jika $X=-$ dan $Y=-$, maka arah adalah $270^{\circ}-\alpha$

4. Jika $X=-$ dan $Y=+$, maka arah adalah $270^{\circ}+\alpha$

5. Jika $X=0$ dan $Y=+$, maka arah adalah $0^{0}$

6. Jika $X=0$ dan $Y=-$, maka arah adalah $180^{\circ}$

7. Jika $X=+$ dan $Y=0$, maka arah adalah $90^{\circ}$

8. Jika $X=-$ dan $Y=0$, maka arah adalah $270^{\circ}$

3) Selanjutnya data hasil perhitungan dikelompokkan. Rampengan (2009) mengklasifikasikan arah arus untuk menganalisis dan mendeskripsikan data hasil pengukuran sebagai berikut :

$$
\begin{aligned}
337,5^{0} & <\mathrm{U} \leq 22,5^{0} \\
22,5^{0} & <\mathrm{TL} \leq 67,5^{0} \\
67,5^{0} & <\mathrm{T} \leq 112,5^{0} \\
112,5^{0} & <\mathrm{TG} \leq 157,5^{0} \\
157,5^{0} & <\mathrm{S} \leq 202,5^{0} \\
202,5^{0} & <\mathrm{BD} \leq 247,5^{\circ} \\
247,5^{0} & <\mathrm{B}<292,5^{0} \\
292,5^{\circ} & <\mathrm{BL} \leq 337,5^{0}
\end{aligned}
$$

4) Setelah dikelompokkan, data selanjutnya disesuaikan dengan urutan posisi geografis ke dalam perangkat lunak Microsoft Excel, kemudian data tersebut dimasukkan ke dalam perangkat lunak surfer. Data akhir hasil olahan perangkat 
lunak surfer ditampilkan dalam bentuk peta, yaitu peta arah pergerakan dan kecepatan arus.

\section{HASIL DAN PEMBAHASAN}

\section{Pasut}

Pasang surut diukur selama pengukuran arus dalam tiga hari (13-15 Oktober 2017) yaitu pada saat bulan perbani akhir di musim pancaroba II. Data pasut ini merupakan acuan untuk sinkronisasi data arus dan pergerakan pasang surut air laut. Data pasut secara lengkap dapat dilihat pada grafik di bawah ini.

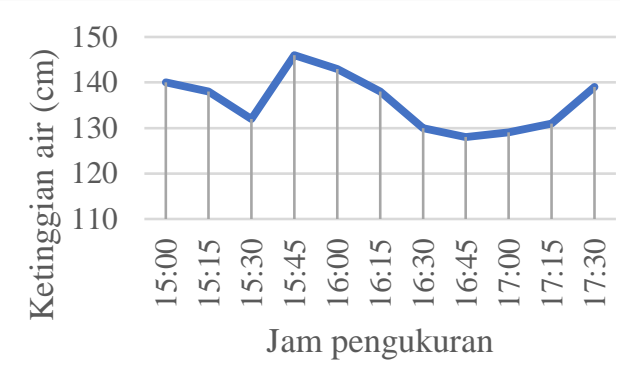

Gambar 2. Hasil pengukuran pasut tanggal 13 Oktober 2017

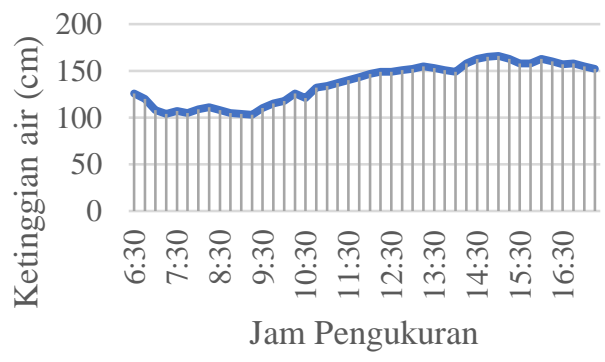

Gambar 3. Hasil pengukuran pasut tanggal 14 Oktober 2017

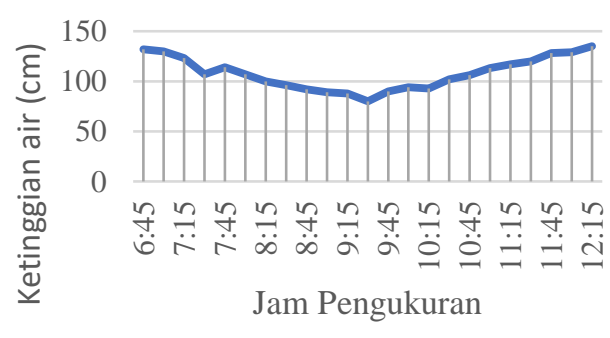

Gambar 4. Hasil pengukuran pasut tanggal 15 Oktober 2017

\section{Resultan Kecepatan dan Arah Arus}

Nilai resultan kecepatan arus yang terukur beragam mulai dari 0,05 knot sampai maksimum 2,50 knot saat air bergerak pasang. Saat air bergerak surut kecepatan berkisar minimum 0,02 hingga maksimum hanya mencapai 1,53 knot.

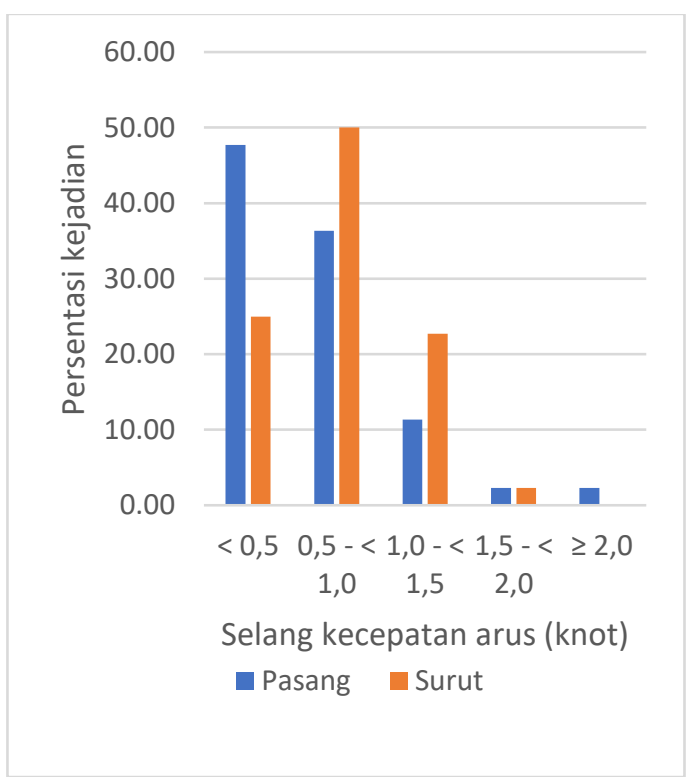

Gambar 5. Persentasi resultan kecepatan arus saat air bergerak pasang dan surut.

Berdasarkan grafik di atas dapat dilihat bahwa kecepatan arus, baik saat pasang maupun saat surut umumnya berkecepatan di bawah 1 knot. Kejadian kecepatan arus saat air bergerak pasang agak lebih banyak yang berkecepatan lebih rendah dibanding dengan kecepatan arus saat air bergerak surut (frekuensi kejadiannya, saat air bergerak pasang terbanyak terukur di bawah 0,5 knot, saat air bergerak surut terbanyak antara 0,5 1,0 knot). Walaupun demikian, resuultan kecepatan arus terukur berkecepatan paling tinggi, terjadi saat air bergerak pasang. Visualisasi kecepatan arus secara spasial dapat dilihat pada Gambar 6 dan 7 . 


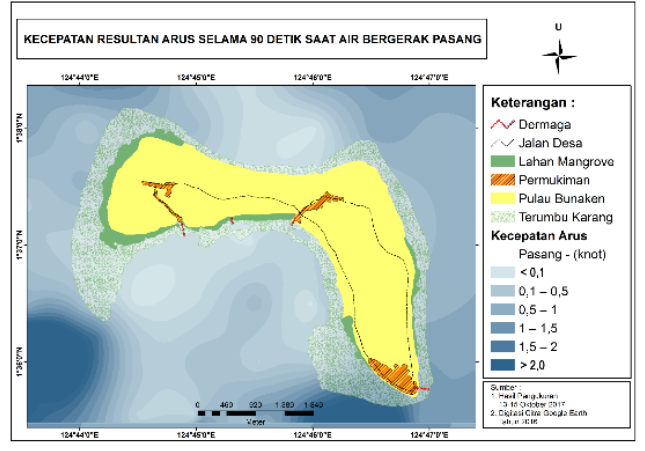

Gambar 6. Resultan kecepatan arus saat air bergerak pasang

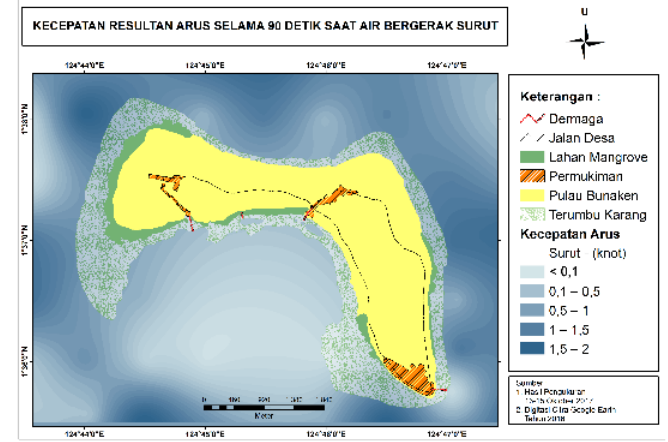

Gambar 7. Resultan kecepatan arus saat air bergerak surut

Pada saat air bergerak pasang, resultan arus yang terukur lebih dominan bergerak ke arah Timur kemudian diikuti oleh arah Utara dan Tenggara dan paling sedikit bergerak ke arah Barat. Sedangkan saat air bergerak surut, arah dominan ke Tenggara, kemudian ke arah Utara dan Barat Laut dan paling sedikit ke arah Barat Daya dan ke arah Barat.

Tabel 2. Frekuensi arah arus

\begin{tabular}{ccr}
\hline Arah & \multicolumn{2}{c}{ Persentasi Kejadian } \\
\cline { 2 - 3 } Arus & Pasang & \multicolumn{1}{c}{ Surut } \\
\hline U & 18,18 & 15,91 \\
TL & 11,36 & 9,09 \\
T & 27,27 & 6,82 \\
TG & 18,18 & 22,73 \\
S & 6,82 & 15,91 \\
BD & 11,36 & 4,54 \\
B & 2,27 & 6,82 \\
BL & 4,54 & 18,18 \\
\hline
\end{tabular}

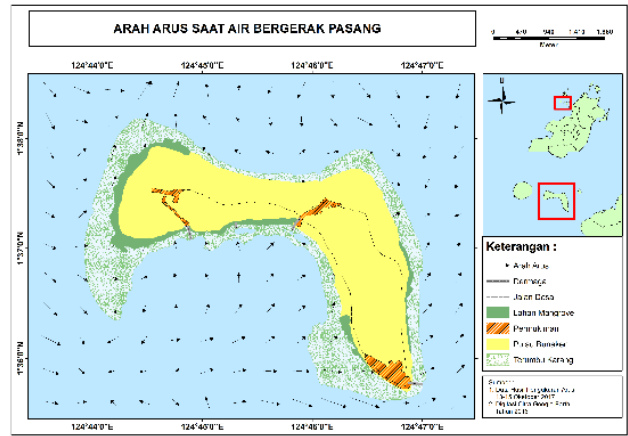

Gambar 8. Resultan arah arus saat air bergerak pasang

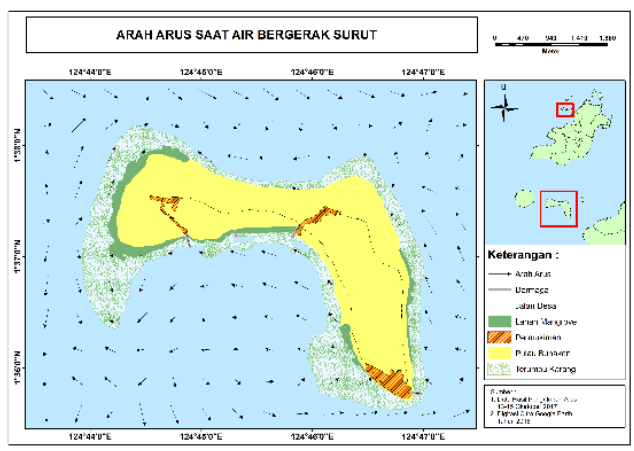

Gambar 9. Resultan arah arus saat air bergerak surut

Saat air bergerak pasang (gambar 8) umumnya massa air bergerak mendekati daratan. Hal ini terlihat jelas di perairan sebelah Selatan Pulau Bunaken. Sedangkan pada saat air bergerak surut (gambar 9) lebih bervariasi tetapi di beberapa bagian perairan Pulau Bunaken, terlihat bahwa arus bergerak menjauhi pulau. Meskipun demikian arah arus yang didapat beragam. Hal ini dapat dilihat di beberapa tempat terutama di perairan selat-selat yang berbatasan langsung dengan daratan misalnya di sebelah Timur terdapat Pulau Siladen, sebelah Barat Pulau Manado Tua, dan di sebelah Utara terdapat Pulau Mantehage.

\section{Fluktuasi Kecepatan dan Arah Arus}

Kecepatan arus yang terukur baik saat pasang maupun surut berfluktuasi atau berubah-ubah. Hampir seluruh perubahan kecepatan arus yang 
Tabel 3. Persentasi fluktuasi kecepatan arus

\begin{tabular}{crr}
\hline $\begin{array}{c}\text { Fluktuasi kec. } \\
\text { Resultan } \\
\text { (knot) }\end{array}$ & \multicolumn{2}{c}{ Persentasi } \\
kejadian (\%) \\
Pasang & \multicolumn{1}{c}{ Surut } \\
\hline$<0,5$ & 93,18 & 93,18 \\
$0,5-<1,0$ & 4,55 & 4,55 \\
$1,0-<1,5$ & - & 2,27 \\
$\geq 1,5$ & 2,27 & - \\
\hline
\end{tabular}

terukur berada di bawah 0,5 knot (konstan) baik saat air bergerak pasang maupun saat air bergerak surut mencakup 93,18\% dari seluruh data. Perubahan kecepatan yang lebih dari 0,5 knot hanya berjumlah sekitar $6,82 \%$.

Saat air bergerak pasang, daerah perairan yang kecepatan arusnya berubah signifikan yaitu di perairan sebelah Barat Daya Pulau Bunaken sementara di daerah lain cenderung stabil (Gambar 10).

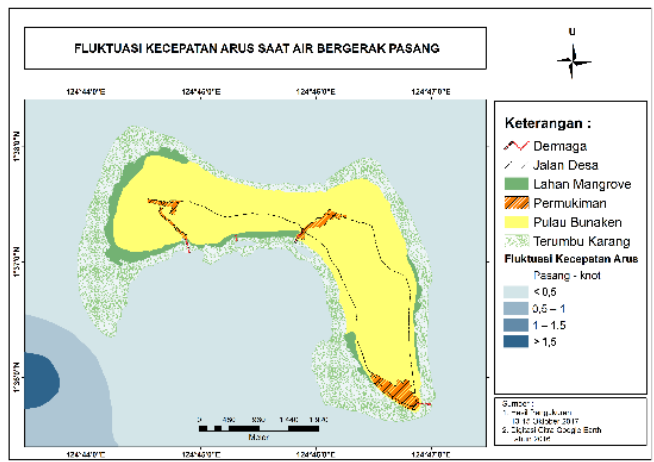

Gambar 10. Fluktuasi kecepatan arus saat air bergerak pasang

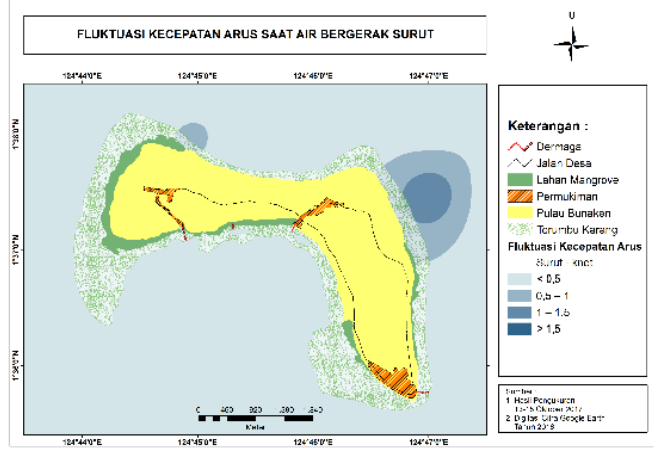

Gambar 11. Fluktuasi kecepatan arus saat air bergerak surut
Sedangkan ketika air bergerak surut perairan yang kecepatan arusnya berubah signifikan yaitu di perairan Timur Laut Pulau Bunaken (Gambar 11). Di lokasi-lokasi lainnya, terdapat perubahan kecepatan namun berdasarkan data, perubahan kecepatan tersebut paling banyak tidak melebihi 0,5 knot. Dengan demikian dapat diketahui bahwa perubahan kecepatan arus memang terjadi, tetapi pada umumnya perubahan tersebut mestinya tidak jauh berbeda dengan kecepatan awal yang terukur.

Berdasarkan hasil ini dapat dikatakan bahwa pergerakan arus yang terjadi di perairan sekitar Pulau Bunaken ini dalam skala temporal yang singkat memiliki kecepatan yang relatif konstan. Dengan demikian hasil pengukuran kecepatan arus di perairan sekitar Pulau Bunaken saat ini dapat dikatakan mewakili kondisi kecepatan arus di kawasan ini saat musim pancaroba II pada periode umur bulan perbani.

Arah arus yang terukur juga berubah-ubah. Baik pda saat pasang maupun surut terdapat perubahan pada arah arus pada beberapa titik pengukuran. Namun jika diperhatikan lebih dalam, sama seperti halnya perubahan kecepatan, arah arus yang terlihat tidak memperlihatkan adanya perubahan arah arus yang berarti. Meskipun demikian terdapat beberapa tempat di mana arah arus berubah arah dengan drastis bahkan berlawanan dengan arah arus pada awal pengukuran.

\section{KESIMPULAN DAN SARAN}

\section{Kesimpulan}

Resultan kecepatan arus saat air bergerak pasang terukur berada pada kisaran 0,05 sampai 2,50 knot, sedangkan saat air bergerak surut berada pada kisaran 0,02 sampai 1,53 knot. Walaupun demikian, saat air 
bergerak pasang hampir $50 \%$ frekuensi kejadian resultan kecepatan arusnya berkecepatan $<0,50$ knot, sedangkan saat air bergerak surut sekitar $50 \%$ frekuensi kejadiannya berada pada resultan kecepatan antara 0,50 sampai 1,00 knot. Frekuensi kejadian resultan arah arus saat air bergerak pasang terbanyak mengarah ke Timur, yaitu sebesar $27,27 \%$. Saat air bergerak surut, resultan arah pergerakan arus terbanyak mengarah ke Tenggara, yaitu sebanyak $22,73 \%$.

Secara spasial, fluktuasi kecepatan dan arah arus perairan sekitar Pulau Bunaken yang terukur pada skala temporal yang singkat (30 detik) memperlihatkan kondisi relatif konstan. Hanya pada beberapa tempat tertentu memperlihatkan kejadian perubahan baik kecepatan dan arah arusnya.

\section{Saran}

Pengukuran arus pada kali ini dilakukan pada saat periode umur bulan perbani dimusim pancaroba II. Oleh karena itu, sangat diharapkan agar penelitian lebih lanjut dapat dilaksanakan terutama pada saat periode umur bulan lain dan di musimmusim yang lain sehingga data-data selanjutnya akan lebih lengkap dan menjelaskan pergerakan arus yang terjadi di perairan sekitar Pulau Bunaken.

\section{DAFTAR PUSTAKA}

Hutabarat, S., Evans, S.T., 1985. Pengantar Oseanografi. Penerbit Universitas Indonesia. Jakarta. 166 hal.

Rampengan, R.M., 2009. Pengaruh Pasang Surut Terhadap Arus Permukaan di Teluk Manado. Jurnal Perikanan dan Kelautan, 5(3):15-19.
Rares. J. J., 2015. Manajemen Pengelolaan Taman Nasional Bunaken Oleh Pemerintah Provinsi Sulawesi Utara. Jurnal LPPM Bidang EkoSosBudKum, 2(2):36-43.

Rompas, M.D., Kusen, J.D., Lasut, M.T., 2015. Strategi alternatif untuk pengelolaan wisata bahari di Pulau Bunaken, Taman Nasional Bunaken, Sulawesi Utara, Indonesia. Jurnal Aquatic Science \& Management, 3(2): 55-57.

Setiawan, F., Kusen J.D., Kaligis, G.J.F., 2013. Perubahan struktur komunitas ikan karang di Taman Nasional Bunaken, Sulawesi Utara. Jurnal Aquatic Science \& Management, 1(2):117-123.

Siwy, A., 2012. Pergerakan Massa Air Permukaan Di Teluk Manado Saat Musim Utara. Skripsi. Fakultas Perikanan dan IImu Kelautan, Universitas Sam Ratulangi. Manado. 71 hal.

Stowe, K., 1987. Essentials of Ocean Science. New York. p 353.

Towoliu, R., 2014. Kondisi terumbu karang pada beberapa pusat penyelaman di Pulau Bunaken, Sulawesi Utara. Aquatic Science \& Management, Edisi Khusus, 2:44-48.

Wagey, B. T., 2017. Morphometric analysis of congeneric seagrasses (Cymodocea rotundata and Cymodocea serrulata) in the coastal areas of Bunaken National Park, North Sulawesi, Indonesia. AACL Bioflux, 10(6).10 p. 